\title{
Monitoring of Hemodialysis by Urea Sensor
}

\author{
尿素センサによる人工腎臓のモニタリング
}

\author{
Masaya SETO, Mitsuo SAITOH, Noriaki KITAMURA, \\ Kouji SHIMAZAKI, Sachio SUGIURA, Kentaro YODA \\ Department of Bio-Medical Engineering, Tokai University \\ 317 Nishino, Numazu, Shizuoka, 410-03 JAPAN
}

TEL.0559-68-1111 ex.4529

( Received 17, November 1994 Accepted 24, March 1995 )

\begin{abstract}
An urea sensor was developed for the determination of urea in dialysate of hemodialysis. The urea sensor was constructed by combining an immobilized enzyme urease membrane with an ammonia electrode. The sensor responded to urea in concentration over 1-100 mg/dl. The sensor is useful for the determination of urea clearance of dialyzer. The sensor can also provide a new laborsaving procedure for the estimation of blood urea concentration by measuring urea concentration in outlet dialysate during hemodialysis treatment.
\end{abstract}

Key words: urea sensor, urease, ammonia electrode, hemodialysis, dialyzer clearance

1.はじめに

人工腎臓による血液透析療法は最も普及率の高い人 工缄器療法であり、我国の慢性透析患者数は 13 万人 にも達している。しかし、現在の血液透析は透析液組 成、透析液流量、血液流量および透析時間が画一的で あり、各患者に対して最適な療法とはなっていない。 そこで、個々の患者の病態に合わせた血液透析を行う ために、除水量および血中溶質濃度を測定して最適化 を計る試みがあり、除水量に関しては除水コントロー ラーが開発されている。血中溶質濃度の測定について は安全性と患者への負担の点から困難が多いため、代 わりに透析液廃液中の除去溶質濃度を測定して数理モ デル1を用いて血中溶質濃度を推算して透析終了時間 を決定する方式が提案され、透析により除去される代 表的な老廃物である尿素についての研究が報告されて いる2,3。一方、透析器の製造においても、性能の指 標として尿素クリアランス、ふるい係数などが用いら れ、尿素の測定が行われている。

本研究においては、血液透析時に透析終了時間を決 定したり、透析器の評価指標としての尿素クリアラン
スを求めるために、試料の希釈や濃縮といった煩雑な 操作なしに簡便で精度の高い尿素測定を可能とする新 しい尿素センサを開発し、透析器の尿素クリアランス の測定および透析液廃液中の尿素測定への尿素センサ の応用について検討した。 オンライン計測に適した尿素検出用バイオセンサと して、固定化ウレアーゼとアンモニア電極、二酸化炭 素電極またはアンモニウムイオン電極とを組み合わせ たセンサなどが試作されている。これらのうち、アン モニア電極を用いるものが、 $\mathrm{N} \mathrm{a}^{+} 、 \mathrm{~K}^{+}$、炭酸ガ スなどの妨害がなく、生体試料の測定に適している。 固定化ウレアーゼとアンモニア電極とを組み合わせた 酵素電極に関しては、アンモニア電極の外側にテフロ

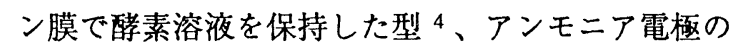
ガス透過膜上に酵素溶液を直接固定化した型 5 、多孔 性テフロン膜に酵素溶液を含浸固定化した膜をアンモ ニア電極の外側に設置した型 6、などが検討されてい るが、再現性良く均質なセンサを作製することが難し いなどの問題点が多いために実用化されていない。 本報告では、容易に入手出来る均質な材料を用いた 
作製の再現性が良く、均質で実用的尿素センサとして、 基質透過性に優れたポリカーボネート多孔性膜とアン モニアガス透過性に優れたポリテトラフルオロエチレ ン膜との間にウレアーゼをグルタルアルデヒド架橋法 により固定化した複合膜とアンモニゥイオン検出用 ガラス電極とを組み合わせた䣼素電極を試作し、人工 腎蔵のモニタリングについて検討した結果を報告する。

\section{2. 実験}

\section{1 試薬等}

ウレアーゼ（E C 3・5・1・5）は東洋紡製診断 薬グレード、牛血清アルブミンはシグマ製結晶グレー ド、グルタルアルデヒドは和光純薬製電子顕微鏡用水 溶液をそれぞれ使用した。その他の試薬は市販特級品 をそのまま使用した。透析液は扶桑薬品製キンダリー 液 $\mathrm{A} \mathrm{F}$ - 2 号を使用した。固定化酵素用の膜担体とし て、ニュクリポア製ニュクリポアメンブレン（孔径 0 .0 $05 \mu \mathrm{m}$ 、材質ポリカーボネート)、アンモニアガス透 過性膜は堀場製作所製アンモニア電極部品のポリテト ラフルオロエチレン多孔性膜をそれぞれ使用した。

\section{2 固定化ウレアーゼ膜の作成}

$1 \mathrm{mM}$ の E D T A を含む $50 \mathrm{mM}$ 燐酸カリウム縓衝 溶液 p H 7.5 (以下K P B と略す) $150 \mu \ell に$

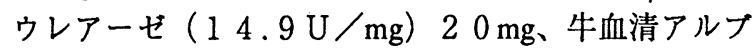
ミン $10 \mathrm{mg}$ を溶解し、氷冷下で $5 \%$ グルタルアルデ ヒド水溶液 $100 \mu \ell$ を加えて混合した。直ちに、 水平に保持した $50 \times 50 \mathrm{~mm}^{2}$ のニュクリポアメンブ レンに均一に流延した。 $4{ }^{\circ} \mathrm{C} て ゙ 20$ 分、室温で 10 分 間放置してゲル化させた。次に、1 Mのグリシンを含

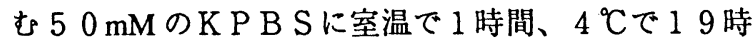
間浸漬して未反応のグルタルアルデヒドを処理した。 K P B S で洗浄後、 5 \%グリセリンを含むK P B Sに

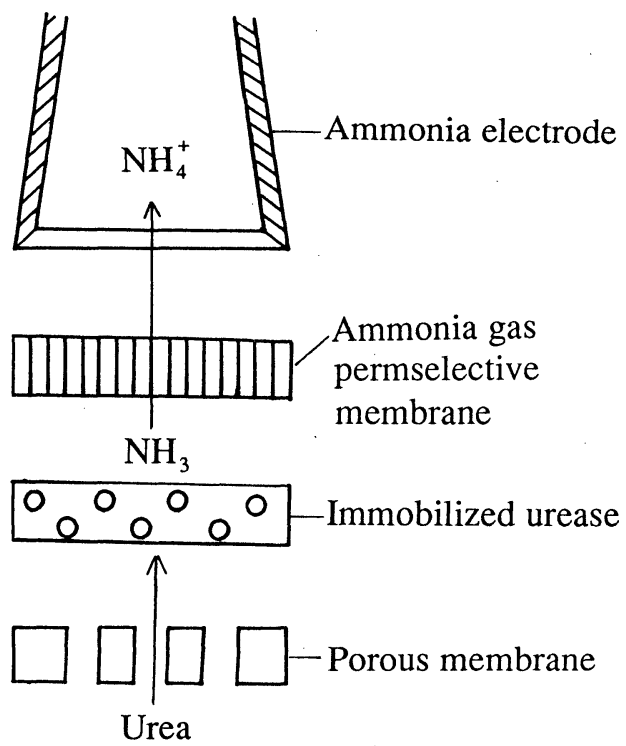

Fig.1. Schema of urea sensor.

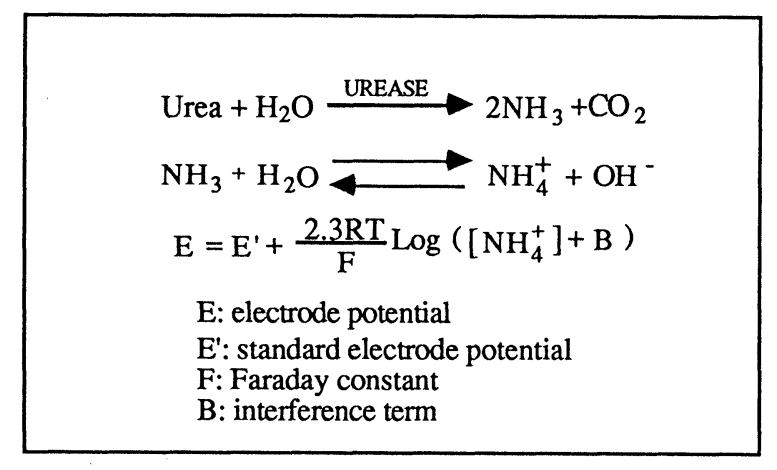

Fig.2.Principle of urea analysis by urea sensor.

1 時間浸漬した。次いで、アンモニア電極用ポリテト ラフルオロエチレン多孔性膜で酵素面を被覆後、 $4{ }^{\circ} \mathrm{C}$ にて風乾して固定化ウレアーゼ膜を得た。

\section{3 尿素センサによる尿素の測定}

固定化ウレアーゼ膜とアンモニア電極用 $\mathrm{p} \mathrm{H}$ 電極と を組み合わせて作成した尿素センサの模式図をFig.1 に示した。測定原理をFig.2に示したが、ポリカーボ ネート多孔性膜を透過した試料中の尿素はウレアーゼ の作用により加水分解されてアンモニアを生成する。 生成したアンモニアはアンモニアガス透過性膜を通過 して電極内部液（塩化アンモニウム水溶液）に溶解し、 $\mathrm{p} \mathrm{H}$ 感応性ガラス電極によって検知される。

透析液に一定量の尿素を溶解した尿素標準液および 試料中の尿素の測定は希釈することなしに、ビーカー に入れた試料にイオンメーターに接続した尿素センサ を直接浸してバッチ法で行った。アンモニア電極用の p H電極は堀場製作所製 $5002 \mathrm{~A}-06 \mathrm{~T}$ 型、イオ ンメーターは堀場製作所製 $\mathrm{N}-8 \mathrm{M}$ 型、記録計は日本 電子科学製ユニコーダーU-2 28 型をそれぞれ使用 した。

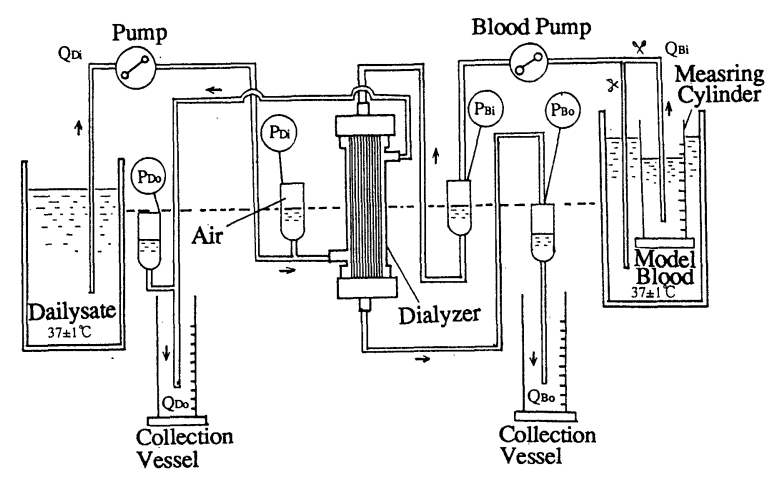

Fig.3. Schematic diagram of clearance test set-up. 
2.4 尿素クリアランスの測定

透析器の尿素クリアランスの測定は日本人工葴器学 会のダイアライザー性能評価基準7を参考にしてFig.3 に示した回路構成とし、以下の実験条件で実施した。

モデル血液（B液）および透析液（D液）の流れは 向流とし、透析器への供給はシングルパスとした。B 液、 $\mathrm{D}$ 液の温度を $37 \pm 1{ }^{\circ} \mathrm{C}$ にコントールし、B液 流量（QBi）とD液流量（QDi）はそれぞれ2 $00 \mathrm{ml}$ $/ \min ( \pm 2 \%)$ と $500 \pm 10 \mathrm{ml} / \min$ とした。膜間 圧力差 TMPは $0 \pm 10 \mathrm{~mm} \mathrm{H}$ g とした。サンプリン グ場所は B 液回路およびD液回路の透析器出口とし、 回路内の流量が一定になった後に $20 \mathrm{ml}$ づつサンプ リングした。透析器はニプロの中空系型 $110 \mathrm{M}$

（限外滤過率 $6.8 \mathrm{ml} / \mathrm{mmHg} / \mathrm{hr}$,尿素クリアランス $173 \mathrm{m \ell} / \mathrm{min}$ ) を使用した。モデル血液には尿素を 一定量含む水溶液を用いた。試料中の尿素濃度は尿素 センサにより測定した出力電位差の值から濃度既知の 標準液について求めた検量線を用いて算出した。

透析器に導入された血液中から透析膜を通過して透 析液側に除去される尿素の除去効率は次式で定義され る尿素クリアランス（CL）によって評価される。

$$
\mathrm{CL}=(\mathrm{CBiQBi}-\mathrm{CBoQBo}) / \mathrm{CBi}
$$

ただし、C Bi：透析器入口側血中尿素濃度、

$\mathrm{CBo}$ : 透析器出口側血中尿素濃度、QBi：供給血液流量、 QBo：流出血液流量である。測定值を上式に代入して 透析器の尿素クリアランスを求めた。尿素クリアラン スは透析器内に導入された血流量のうち、着目する尿 素濃度が計算上ゼロとなる流量を意味する。

\section{3 . 結果}

3.1 尿素センサによる尿素の測定

透析液に一定量の尿素を溶解した標準試料中の尿素 濃度に対する尿素センサの出力電位差をプロットした 結果をFig.4 に示した。透析液揖よびモデル血液中の 尿素が 1 〜 $100 \mathrm{mg} / \mathrm{dl}$ の範囲で測定できた。

\section{2 透析器の尿素クリアランスの評価}

各時間毎にサンプリングした $\mathrm{B}$ 液および $\mathrm{D}$ 液につい て測定した尿素センサの出力電位差からFig.4の検量 線を用いて算出した尿素濃度值をTable 1 に示した。 8 分および 12 分の值の平均值から実験に用いた透析 器の尿素クリアランスを求めた結果、1 $72 \mathrm{ml} / \mathrm{min}$ が得られた。この值はメーカーがウレアーゼ・イン ドフェノール法に基づく比色法によって求めた值 $173 \mathrm{~m} \ell / \min$ とほほ一致した。

\section{4. 考察}

Figure4 の結果から、尿素センサによる尿素の測定 は 1 〜 $1000 \mathrm{mg} / \mathrm{dl}$ の濃度範囲をカバーすることが 可能である。患者体内から動脈血を導き出して人工膜 を介して透析液と接触させて血液中の尿素などの老廃
○ Model Blood

$\square$ Dialysate

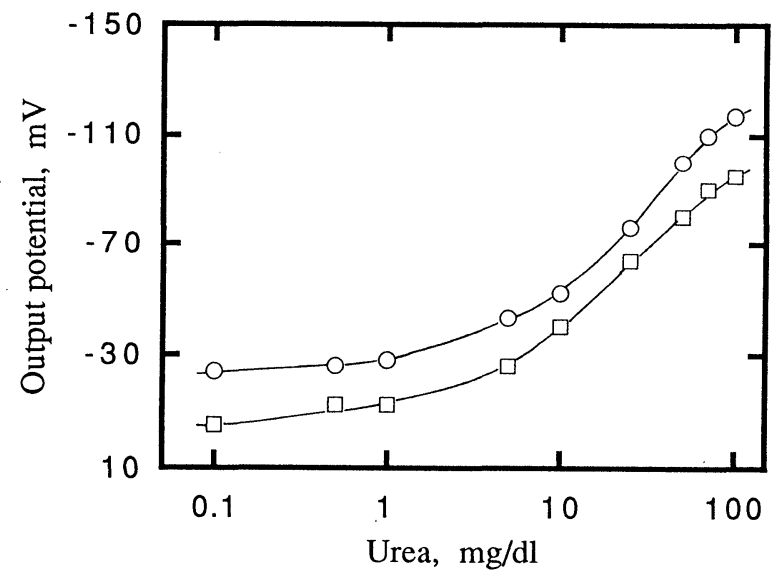

Fig.4. Standard curve for urea analysis.

Table 1. Experimental data on clearance measurement of dialyzer.

\begin{tabular}{|ccccc}
\hline Dialysis time & \multicolumn{4}{c}{ Pressure $(\mathrm{mmHg})$} \\
$(\mathrm{min})$ & PDi & PDo & PBi & PBo \\
\hline 8 & 18 & 10 & 25 & 2 \\
12 & 15 & 11 & 25 & 2 \\
\hline
\end{tabular}

\begin{tabular}{cccc}
\hline Urea concentration(mg/dl) \\
CDi & CDo $C_{\text {Bi }}$ & $C_{B o}$ \\
\hline 0 & 26 & 100 & 14 \\
0 & 23 & 100 & 14 \\
\hline
\end{tabular}

物を拡散により除去して静脈に戻す透析療法において は、1回の血液透析で除去される尿素量は 12 $30 \mathrm{~g}$ であり、使用する透析液量は 150 ～ 300 l であるから、透析液中の尿素濃度としては 0 〜 $20 \mathrm{mg} / \mathrm{dl}$ 程度である。したがって、尿素センサで は希釈することなしに透析液中の尿素を測定すること ができる。

本実験の結果から算出された透析器の尿素クリアラ ンスの值とメーカーが測定したウレアーゼ・インドフ エノール法による尿素クリアランスの值が一致したこ とにより、簡便な尿素センサ法が操作の煩雑な比色法 に代って、製造工程における透析器の性能評価に利用 できることが明かになった。

従来、オンラインで透析液廃液中の尿素濃度を簡単 に測定できなったが、尿素センサを利用することに よりオンライン化が容易となり、個々の患者に最適な 透析を実施できる可能性がある。必要透析時間を推定 するために、人体を 1 つのタンクとして考える1プー 
ルモデル 8 を適用する。透析器の尿素クリアランスを CL、透析開始 $\mathrm{t}$ 分後の透析液廃液中の尿素濃度およ び血中尿素濃度をそれぞれ $\mathrm{CD}(\mathrm{t})$ および $\mathrm{C} \mathrm{B}(\mathrm{t})$ 、透析 液流量を QD として、透析中の除水を無視した場合、 1 プールモデルでは C B(t) は次式となる。

$$
\mathrm{CB}(\mathrm{t})=\mathrm{CD}(\mathrm{t}) \times \mathrm{QD} / \mathrm{CL}
$$

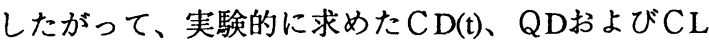
の值から血中尿素濃度を推定することができ、必要透 析時間の推定が可能となり、採血して血中尿素濃度を 測定する必要がない。これにより、患者に必要にして 充分な透析を実施することができる。

実際に尿素センサを透析システムに組み込むために は、電極の校正や洗浄についての詳細な検討が必要で あると考えられる。

\section{References}

1. J.A.Sargent, F.A.Gotch, Kidney Int., 18, S2 (1980)

2. J.Kamisina, et al, Jpn. J. Artif. Organs, 13 , 735(1984)

3. R.Lindsay, et al, ASAIO Abstract(1993)p.90

4. D.S.Papastathopoulos, G.A.Rechnitz, Anal. Chem. Acta, 79, 17(1975)

5. M.Mascini, G.G.Guilbault, Anal. Chem., 49, 795(1977)

6. M.Hatou, et al, J. Chem. Soc. of Japan, 1981, 1172(1981)

7. The Standard for Evaluation of Dialyser, Ed by Jpn. Society for Artif. Organs, Tokyo(1982)

8. K.Sakai, Fundamentals of Blood purification for Dialysis Stuff, IPC Pubisher, Tokyo(1989) p.50

'94 SAS Intelligent : Symposium 